Tropical Journal of Pharmaceutical Research March 2021; 20 (3): 453-458

ISSN: $1596-5996$ (print); 1596-9827 (electronic)

(C) Pharmacotherapy Group, Faculty of Pharmacy, University of Benin, Benin City, 300001 Nigeria.

Available online at http://www.tjpr.org

Original Research Article

http://dx.doi.org/10.4314/tjpr.v20i3.2

\title{
6-Methyl-1-(3-(trifluoromethyl)phenyl)-1H-pyrazolo[4,3- c]pyridin-4(5H)-one (FMPPP) exhibits anti-proliferative effect on prostate cancer via autophagy induction and mTOR/p70S6K inhibition
}

\author{
Qingbin Cui ${ }^{1}$, Xiaozhu $\mathrm{Yu}^{2 *}$ \\ ${ }^{1}$ Department of Surgery, Nanjing University of Science and Technology Hospital, Nanjing-210014, China, ${ }^{2}$ Department of \\ Internal Medicine, Nanjing University of Science and Technology Hospital, Nanjing-210014, China
}

*For correspondence: Email: simonarapposelliap@gmail.com

Sent for review: 15 October 2020

Revised accepted: 26 February 2021

\begin{abstract}
Purpose: To investigate 6-methyl-1-(3-(trifluoromethyl)phenyl)-1H-pyrazolo[4,3-c]pyridin-4(5H)-one (FMPPP) as anti-proliferative agent against prostate cancers.

Methods: The FMPPP-mediated changes in cell proliferation were measured using cell counting kit-8 (CCK-8). Flow cytometry and propidium iodide staining were used for cellular DNA content determination. Proteins expression in cells was probed by western blotting assay.

Results: A significant $(p<0.05)$ dose-dependent suppression of DU145 and PC 3 cell proliferation was observed following FMPPP treatment. FMPPP treatment at $20 \mu \mathrm{M}$ raised DU145 cell fraction to $75.08 \pm$ $4.87 \%$ in $G 1$ phase when compared to $48.32 \pm 3.44 \%$ for control. The population of PC 3 cells in G1phase reached to $72.78 \pm 5.21 \%$ on treatment with $20 \mu M$ FMPPP compared to $49.65 \pm 4.62 \%$ in control. The FMPPP treatment of DU145 and PC-3 cells elevated LC3-Il expression and suppressed SQSTM1/p62 expression. In FMPPP-treated DU145 and PC-3 cells, $p$-ERK1/2 level was promoted whereas $m$ TOR and p70S6K phosphorylation significantly decreased. Exposure to U0126 (ERK pathway inhibitor) reduced FMPPP-induced increase of LC3-II expression and promotion of p-ERK1/2 level in DU145 and PC-3 cells.

Conclusion: FMPPP exhibits anti-proliferative effect by increasing autophagy in prostate cancer cells. The cytotoxicity of FMPPP involves elevation of ERK1/2 phosphorylation and targeting mTOR pathway in DU145 and PC-3 cells. Therefore, FMPPP may be beneficial for the treatment of prostate cancer in patients.
\end{abstract}

Keywords: Prostate cancer, Phosphorylation, Drug development, Autophagy

This is an Open Access article that uses a fund-ing model which does not charge readers or their institutions for access and distributed under the terms of the Creative Commons Attribution License (http://creativecommons.org/licenses/by/4.0) and the Budapest Open Access Initiative (http://www.budapestopenaccessinitiative.org/read), which permit unrestricted use, distribution, and reproduction in any medium, provided the original work is properly credited.

Tropical Journal of Pharmaceutical Research is indexed by Science Citation Index (SciSearch), Scopus, International Pharmaceutical Abstract, Chemical Abstracts, Embase, Index Copernicus, EBSCO, African Index Medicus, JournalSeek, Journal Citation Reports/Science Edition, Directory of Open Access Journals (DOAJ), African Journal Online, Bioline International, Open-J-Gate and Pharmacy Abstracts

\section{INTRODUCTION}

Prostate cancer is the most common type of malignant tumor detected in men and its incidence is increasing worldwide every year
$[1,2]$. It is considered as a highly complicated type of cancer caused by changes in intrinsic as well extrinsic processes in various kinds of cells [3]. Multiple strategies like surgical removal, hormonal therapy, radiation/chemotherapies and 
very high-intensity ultrasound either alone or in combination are used to inhibit prostate tumor growth [4]. Autophagy regulates homeostasis at cellular level by eliminating dysfunctional proteins as well as organelles from cells [5]. It increases survival response and is triggered by various stresses like viral infections and nutrient starvation to cells [6]. Activation of autophagy by cellular stimuli result in programmed but nonapoptotic death of cells [7]. Moreover, in mammalian cells regulation of autophagy is associated with mammalian target of rapamycin (mTOR) pathway [8]. Another pathway known as extracellular signal-regulated kinases $1 / 2$ (ERK1/2) also plays significant role in regulating the autophagy [9].

Pyrazolo[4,3-c]pyridin-4(5H)-ones have been demonstrated as potentially attractive heteroaromatic compounds in drug development programme [10].

The structural arrangement of hydrogen bonddonating and accepting groups in the bicyclic scaffold fulfils the demand of competitive ATP binding to kinases [11]. The pharmacological implications of pyrazolo[4,3-c]pyridin-4(5H)-ones has led to synthesis and investigation of these compounds for diverse medicinal fields. Medicinal chemistry is dependent on synthesis of chemical compounds which can interact with several enzymes to demonstrate efficient pharmacokinetic properties [11]. The bicyclic heterocyclic aromatic compounds are known for pharmacokinetic properties and are preferred in medicinal chemistry because of relatively easy synthetic methods [11]. In the present study, the anti-proliferative potential and underlying mechanism of 6-methyl-1-(3(trifluoromethyl)phenyl)-1H-pyrazolo[4,3-

c]pyridin-4(5H)-one (FMPPP; Figure 1) against prostate cancers was investigated.

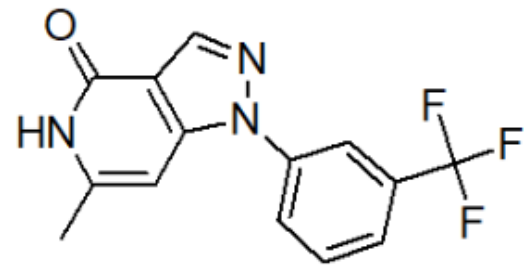

Figure 1: Structure of 6-methyl-1-(3(trifluoromethyl)phenyl)-1H-pyrazolo[4,3-c]pyridin$4(5 \mathrm{H})$-one (FMPPP)

\section{EXPERIMENTAL}

\section{Cell lines and culture}

The cell lines, PNT2 DU145 and PC-3 were provided by American Type cell Culture
Collection (Manassas, VA, USA) and maintained in DMEM. The medium was also supplemented with antibiotics such as $1 \%$ penicillin/ streptomycin (Sigma-Aldrich) and fetal bovine serum $(10 \%)$. Cells were cultured in incubator at $37^{\circ} \mathrm{C}$ and under $5 \% \mathrm{CO}_{2}$ humid atmosphere.

\section{Cell viability assay}

To measure changes in proliferation by FMPPPtreatment cell counting kit-8 (CCK-8; Inc., Kumamoto, Japan) was used. The PNT2, DU145 and PC-3 cells were distributed at $1 \times 10^{5}$ cells/well density in 96-well plates containing culture medium, $10 \%$ FBS and antibiotics. Incubation in an incubator under $5 \% \mathrm{CO}_{2}$ atmosphere was carried out for $12 \mathrm{~h}$ at $37{ }^{\circ} \mathrm{C}$. The cells were treated with FMPPP at 1.5, 3.0, $6.0,12$ and $20 \mu \mathrm{M}$ in $10 \mu \mathrm{L}$ concentrations for 48 h. At completion, CCK-8 $(10 \mu \mathrm{l})$ was poured into each well to incubate cells for $3 \mathrm{~h}$ more. Measurement of absorbance for each well was made at $457 \mathrm{~nm}$ in microplate reader to determine cell viability.

\section{Cell cycle analysis}

Cells treated with FMPPP at $20 \mu \mathrm{M}$ or untreated cells were trypsinized at $48 \mathrm{~h}$ of incubation and then fixed in ethyl alcohol $(70 \%)$ for overnight. Then washing of cells was done in PBS two times followed by centrifugation at $230 \times \mathrm{g}$ for 15 min. The cells were treated for $10 \mathrm{~min}$ with $50 \mu \mathrm{l}$ of RNase before staining with $50 \mu \mathrm{g} / \mathrm{ml}$ solution of propidium iodide (Sigma-Aldrich) at room temperature. Following $1 \mathrm{~h}$ of staining, cellular DNA was examined using a FACSAria-Il flow cytometer (BD Biosciences, San Jose, CA, USA).

\section{Western blot analysis}

The cells treated with FMPPP at $20 \mu \mathrm{M}$ or untreated cells were collected at $48 \mathrm{~h}$ of incubation and then washed in ice-cold PBS. The cells were treated with lysis buffer [NP-40 (1\%), $\mathrm{NaPPi}(5 \mathrm{mM}), \mathrm{NaCl}(150 \mathrm{mM})$, Tris-HCL (20 $\mathrm{mM} ; \mathrm{pH} 7.5), \mathrm{Na}_{3} \mathrm{VO}_{4}(5 \mathrm{mM}), \mathrm{PMSF}(1 \mathrm{mM})$ and leupeptin $(10 \mu \mathrm{g} / \mathrm{mL})]$ to obtain lysate. After 40 min, lysate was subjected to centrifugation for 20 $\min$ at $13,000 \times \mathrm{g}$ and protein level in the lysate was estimated using Bradford method. The proteins were resolved on 10-15 \% SDS-PAGE and subsequently transferred to PVDF membranes. Incubation of membrane for $1.5 \mathrm{~h}$ was carried out at room temperature with $5 \%$ non-fat milk to block non-specific sites. Proteins were probed by overnight incubation of membranes with primary antibodies at $4^{\circ} \mathrm{C}$. Washing with PBS/Tween-20 (0.1 \%) was 
followed by incubation at room temperature with horseradish peroxidase-conjugated secondary antibodies for $1 \mathrm{~h}$. The blots were detected using enhanced chemiluminescence reagent (ECL) and $X$-ray films. The primary antibodies included against: LC3II, p-ERK1/2, SQSTM1/p62, ERK1/2, mTOR, p-mTOR, p-p70S6K and $\beta$-actin (Cell Signaling Technology, Inc., Danvers, MA, USA).

\section{Statistical analysis}

The data are expressed as mean \pm standard deviations of triplicate measurements. The statistical analysis of obtained data was made using one-way analysis of variance (ANOVA) and Bonferroni's post-hoc tests for multiple comparisons. At $p<0.05$, differences were taken as statistically significant.

\section{RESULTS}

\section{Proliferation suppression by FMPPP in DU145 and PC-3 cells}

Proliferation changes by FMPPP-treatment in PNT2, DU145 and PC-3 cells at $48 \mathrm{~h}$ were measured to assess its cytotoxicity (Figure 2). The cells exposed to FMPPP at 1.5, 3.0, 6.0, 12 and $20 \mu \mathrm{M}$ doses and then subjected to Cell Counting assay. In PNT2 cells proliferation was not changed by FMPPP treatment in 1.5 to 20 $\mu \mathrm{M}$ concentration range. However, proliferation of FMPPP-treated DU145 and PC-3 cells showed significant $(p<0.05)$ dose-dependent suppression when compared to control. In FMPPP-treated DU145 cells, proliferation was suppressed to 88.26 and $19.53 \%$, respectively at dose of 1.5 and $20 \mu \mathrm{M}$ doses. Proliferation of 1.5 and $20 \mu \mathrm{M}$ FMPPP-treated PC-3 cells was reduced to 90.42 and $21.72 \%$, respectively at 48 h.

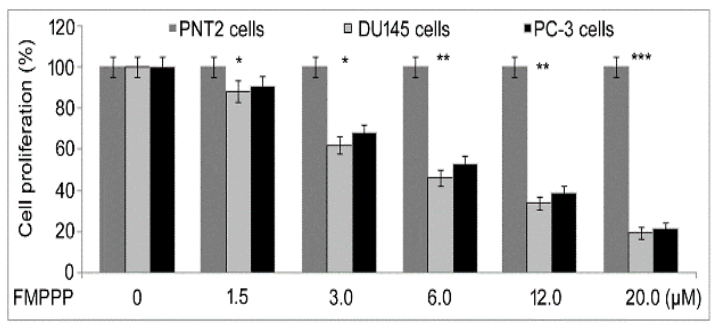

Figure 2: Effect of FMPPP on PNT2, DU145 and PC-3 cells. The FMPPP treatment at 1.5, 3.0, 6.0, 12 and $20 \mu \mathrm{M}$ was followed by proliferation measurement of normal (PNT2) and cancer (DU145 and PC-3) cells at $48 \mathrm{~h}$ using Cell Counting assay. ${ }^{*} P<0.0476$, ${ }^{* *} p<$ 0.0196 and ${ }^{* * *} p<0.0109$ vs. untreated cells

\section{Cell cycle arrest by FMPPP in G1-phase}

Distribution of DNA in FMPPP treated or untreated DU145 and PC-3 cells were examined by flow cytometry (Figure 3). In DU145 and PC-3 cells FMPPP treatment at $20 \mu \mathrm{M}$ dose raised fraction of cells in G1 phase significantly compared to untreated cells. Treatment with FMPPP at $20 \mu \mathrm{M}$ raised DU145 cell fraction to $75.08 \pm 4.87 \%$ in $\mathrm{G} 1$ phase when compared to $48.32 \pm 3.44 \%$ in untreated cells. The G1-phase PC-3 cell population increased to $72.78 \pm 5.21 \%$ on treatment with $20 \mu \mathrm{M}$ FMPPP when compared to $49.65 \pm 4.62 \%$ in untreated cells. The DU145 cellular count in G2/M-phase reduced to $17.41 \pm 2.14 \%$ (control $28.20 \pm 3.08$ $\%$ ) and in S-phase to $8.27 \pm 213 \%$ (control $23.30 \pm 3.08 \%)$ on treatment with $20 \mu \mathrm{M}$ FMPPP. In case of PC-3 cellular population in G2/M-phase reduced to $18.51 \pm 2.19 \%$ (control $30.51 \pm 3.15 \%)$ and in S-phase to $8.45 \pm 213 \%$ (control $19.61 \pm 3.54 \%$ ) on treatment with $20 \mu \mathrm{M}$ FMPPP.
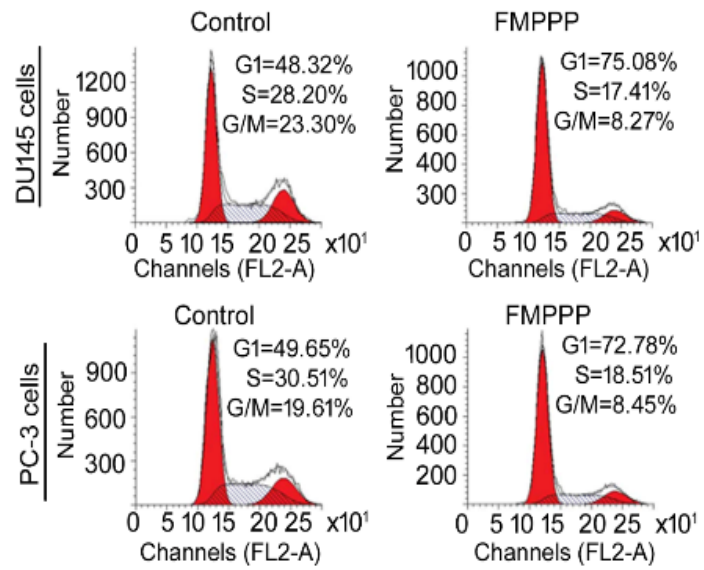

Figure 3: Effect of FMPPP on cell cycle progression. The FMPPP treatment at $20 \mu \mathrm{M}$ dose was followed by Annexin V-FITC/PI staining of DU145 and PC-3 cells at $48 \mathrm{~h}$ to assess the DNA content distribution

\section{Autophagy activation by FMPPP in DU145 and PC-3 cells}

Effect of $20 \mu \mathrm{M}$ FMPPP dose on markers of autophagy in DU145 and PC-3 cells was analyzed by western blotting (Figure 4). Treatment with FMPPP $(20 \mu \mathrm{M})$ for $48 \mathrm{~h}$ markedly promoted LC3-II expression in DU145 and PC-3 cells when compared to untreated cells. The SQSTM1/p62 expression in FMPPP $(20 \mu \mathrm{M})$ treated DU145 and PC-3 cells was significantly $(p<0.05)$ suppressed at $48 \mathrm{~h}$ relative to untreated cells. 


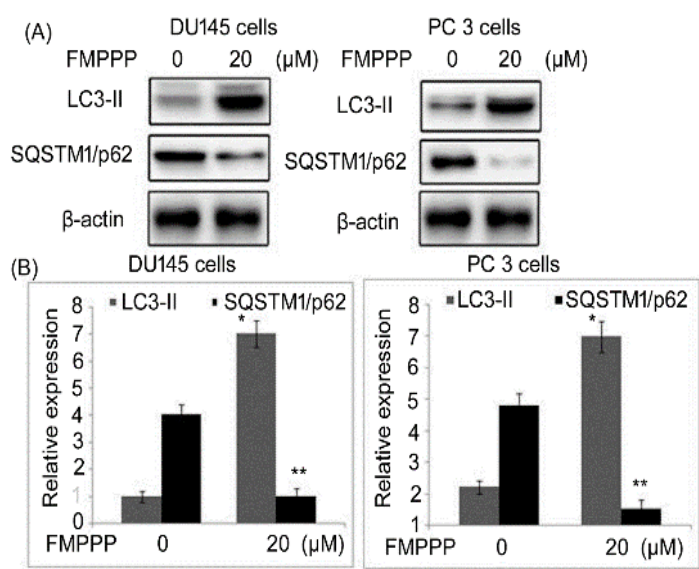

Figure 4: Effect of FMPPP on markers of autophagy. (A) The FMPPP treatment of DU145 and PC-3 cells was followed by LC3-II and SQSTM1/p62 expression assessment at $48 \mathrm{~h}$ using western blotting. (B) Immunoblots were quantified. ${ }^{*} P<0.05$ and ${ }^{* *} p<0.01$ vs. untreated cells

FMPPP regulates $p$-ERK1/2 and mTOR signaling in DU145 and PC-3 cells

In FMPPP-treated DU145 and PC-3 cells elevated $p$-ERK1/2 expression was observed compared to untreated cells (Figure 5). The FMPPP treatment of DU145 and PC-3 cells down-regulated mTOR phosphorylation significantly relative to untreated cells. The p70S6K phosphorylation in DU145 and PC-3 cells was also suppressed on treatment with 20 $\mu \mathrm{M}$ dose of FMPPP.

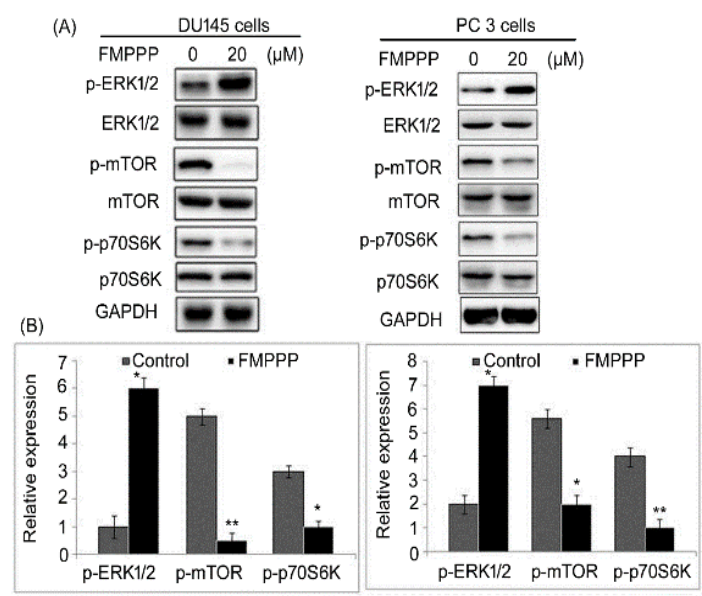

Figure 5: Effect of FMPPP on $m T O R$ and ERK pathways. (A) The FMPPP treatment of DU145 and PC-3 cells was followed by ERK1/2, mTOR and p70S6K activation assessment at $48 \mathrm{~h}$ using western blotting. (B) Immunoblots were quantified. ${ }^{*} p<0.0476$ and ${ }^{* *} p<0.0189$ vs. untreated cells

\section{Effect of U0126 FMPPP induced p-ERK1/2 and mTOR signaling in DU145 and PC-3 cells}

Exposure to U0126 (ERK pathway inhibitor) reduced FMPPP-induced increase in LC3-II expression in DU145 and PC-3 cells (Figure 6). The elevated p-ERK1/2 expression was effectively alleviated by U0126 exposure in DU145 and PC-3 cells. Moreover, U0126 exposure elevated mTOR phosphorylation and p70S6K activation in FMPPP-treated DU145 and PC-3 cells.
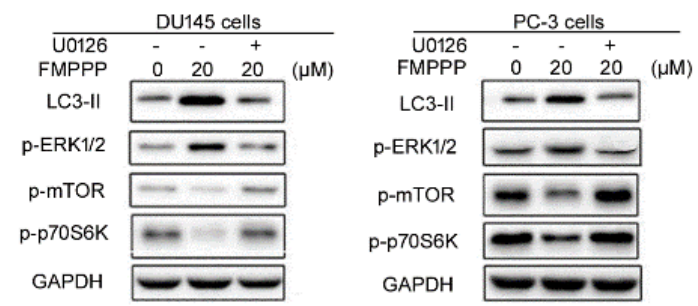

Figure 6: Effect of U0126 exposure on mTOR and ERK pathways in FMPPP treated cells. The U0126exposed DU145 and PC-3 cells were treated with FMPPP and LC3-II expression, ERK1/2, mTOR and p70S6K activation assessment was made by western blotting

\section{DISCUSSION}

Autophagy, a process which transfers intracellular unwanted constituents to lysosomes for decomposition plays crucial role in maintaining homeostatic in cells. Studies have reported activation of autophagy via multiple factors in tumor cells on administration of anticancer drugs [12,13]. Cell death via nonapoptotic pathway is induced by activation of autophagy in tumor cells [14]. The main indicator of cellular autophagy is the formation of LC-3II [15]. There is increased LC3 puncta formation during the cell death induced by autophagy [15]. Besides, p62 levels are suppressed during autophagy because of its degradation along with the autophagosomal contents in autophagosomes [16]. The hallmark of autophagic flux is the breakdown of SQSTM1/p62 in various cells [17].

In the present study, cytotoxicity of FMPPP was investigated against PNT2 (normal), DU145 and PC-3 (carcinoma) cells. The FMPPP treatment decreased proliferation of DU145 and PC-3 cancer cells selectively and significantly without affecting PNT2 cells. This indicates that FMPPP exhibits cytotoxic effect on DU145 and PC-3 cancer cells. Flow cytometry of FMPPP treated cells demonstrated arrest of cell cycle in G1phase which was evident by higher cell fraction. 
For further mechanistic clarification effect of FMPPP on markers of autophagy was analyzed by western blotting. In FMPPP treated DU145 and PC-3 cells marked elevation in LC3-II expression was observed when compared to untreated cells. Moreover, SQSTM1/p62 expression in FMPPP-treated DU145 and PC-3 cells showed a marked down-regulation relative to untreated cells. These findings revealed that FMPPP treatment excessively activates autophagy in prostate cancer cells to suppress proliferation.

Nutrient starvation mediated cell autophagy is regulated by two important pathways known as $m$ TOR and ERK1/2 pathways. Activation of ERK pathway is associated with cadmium or TNFa treatment of the cells resulting in autophagy [18]. Moreover, ERK is directly activated in cells by phosphorylated-MEK over-expression leading to autophagic death [19]. Studies demonstrated that cellular autophagy is negatively regulated following AKT/mTOR activation [20]. In the present study, FMPPP-treatment of DU145 and PC-3 cells elevated $p-E R K 1 / 2$ expression when compared to untreated cells.

In FMPPP-treated DU145 and PC-3 cells downregulation of $\mathrm{mTOR}$ phosphorylation was observed significantly relative to untreated cells. Moreover, p70S6K phosphorylation in DU145 and PC-3 cells was also suppressed on treatment with FMPPP. The activity of MAPK/ERK kinases such as MEK1 and MEK2 at cellular level is inhibited on treatment with U0126 and therefore is used as selective inhibitor for ERK1/2 activation [21]. In the present study U0126 exposure alleviated FMPPP-induced increase of LC3-II expression in DU145 and PC-3 cells. It elevated p-ERK1/2 expression, mTOR phosphorylation and $\mathrm{p} 70 \mathrm{~S} 6 \mathrm{~K}$ activation in FMPPP treated DU145 and PC-3 cells.

\section{CONCLUSION}

FMPPP exhibits anti-proliferative effect by activating autophagy in prostate cancer cells. Its cytotoxicity involves elevation of ERK1/2 phosphorylation and targeting mTOR pathway in DU145 and PC-3 cells. Therefore, FMPPP is a potential treatment strategy for prostate cancer.

\section{DECLARATIONS}

\section{Conflict of interest}

No conflict of interest is associated with this work.

\section{Contribution of authors}

We declare that this work was done by the author(s) named in this article and all liabilities pertaining to claims relating to the content of this article will be borne by the authors. Yanlin Wu conceived and designed the study; Weichong Zhao, Lei Ning, Lihui Wang, Lei Qi, Ruihong Yang - collected and analyzed the data; Weichong Zhao, Lei Ning, Lihui Wang, Lei Qi wrote the manuscript. Yanlin Wu - approved final version of the manuscript. All authors read and approved the manuscript for publication.

\section{Open Access}

This is an Open Access article that uses a funding model which does not charge readers or their institutions for access and distributed under the terms of the Creative Commons Attribution License (http://creativecommons.org/licenses/by/ 4.0) and the Budapest Open Access Initiative (http://www.budapestopenaccessinitiative.org/rea d), which permit unrestricted use, distribution, and reproduction in any medium, provided the original work is properly credited.

\section{REFERENCES}

1. Longning $W$, Lei $W$, Sen $W$, Xiaodong $W$, Daqing S. The Effects of (11R)-13-(6-Nitroindazole)-11,13Dihydroludartin on Human Prostate Carcinoma Cells and Mouse Tumor Xenografts. Med Sci Monit 2020; 26 : e920389.

2. Cuzick J, Thorat MA, Andriole G, Brawley OW, Brown $P H$, Culig Z, Eeles RA, Ford LG, Hamdy FC, Holmberg $L$, et al. Prevention and early detection of prostate cancer. Lancet Oncol 2014; 15: e484-e492.

3. McKenzie S, Kyprianou N. Apoptosis evasion: the role of survival pathways in prostate cancer progression and therapeutic resistance. J Cell Biochem 2006; 97: 18-32.

4. Thakur MK, Vaishampayan U. Multifaceted and personalized therapy of advanced prostate cancer. Curr Opin Oncol 2016; 28: 222-231.

5. Lum JJ, Bauer DE, Kong M, Harris MH, Li C, Lindsten T, Thompson CB. Growth factor regulation of autophagy and cell survival in the absence of apoptosis. Cell 2005; 120: $237-248$.

6. Klionsky DJ, Abdalla FC, Abeliovich $H$, Abraham RT, AcevedoArozena A, Adeli $K$, Agholme L, Agnello $M$, Agostinis $P$, Aguirre-Ghiso JA, et al. Guidelines for the use and interpretation of assays for monitoring autophagy. Autophagy 2012; 8: 445-544.

7. Bursch W. The autophagosomal-lysosomal compartment in programmed cell death. Cell Death Differ 2001; 8: 569-581.

8. Pyo JO, Nah J, Jung YK. Molecules and their functions in autophagy. Exp Mol Med 2012; 44: 73-80.

Trop J Pharm Res, March 2021; 20(3): 457 
9. Cagnol S, Chambard JC. ERK and cell death: Mechanisms of ERK-induced cell death-apoptosis, autophagy and senescence. FEBS J 2010; 277: 2-21.

10. Smyth LA, Matthews TP, Horton PN, Hursthouse MB, Collins I. Synthesis and reactivity of 3-amino- $1 \mathrm{H}$ pyrazolo[4,3-c]pyridin-4(5H)-ones: development of a novel kinase-focused library. Tetrahedron 2010; 66(15): 2843-2854.

11. Hert J, Irwin JJ, Laggner C, Keiser MJ, Shoichet BK. Quantifying biogenic bias in screening libraries. Nat. Chem. Biol. 2009; 5: 479-483.

12. Shimizu S, Kanaseki T, Mizushima N, Mizuta $T$, Arakawa-Kobayashi S, Thompson CB, Tsujimoto $Y$. Role of Bcl-2 family proteins in a non-apoptotic programmed cell death dependent on autophagy genes. Nat Cell Biol 2004; 6: 1221-1228.

13. Bolt AM, Zhao F, Pacheco S, Klimecki WT. Arseniteinduced autophagy is associated with proteotoxicity in human lymphoblastoid cells. Toxicol Appl Pharmacol 2012; 264: 255-261.

14. Levine $B$, Klionsky DJ. Development by self-digestion: Molecular mechanisms and biological functions of autophagy. Dev Cell 2004; 6: 463-477.

15. Kabeya $Y$, Mizushima $N$, Ueno $T$, Yamamoto $A$, Kirisako $T$, Noda T, Kominami E, Ohsumi Y, Yoshimori T. LC3, a mammalian homologue of yeast Apg8p, is localized in autophagosome membranes after processing. EMBO J 2000; 19: 5720-5728.

16. Klionsky DJ. Coming soon to a journal near you-the updated guidelines for the use and interpretation of assays for monitoring autophagy. Autophagy 2014; 10: 1691.

17. Deretic V, Levine B. Autophagy, immunity, and microbial adaptations. Cell Host Microbe 2009; 5: 527-549.

18. Sivaprasad U, Basu A. Inhibition of ERK attenuates autophagy and potentiates tumour necrosis factoralpha-induced cell death in MCF-7 cells. J Cell Mol Med 2008; 12: 1265-1271.

19. Corcelle E, Nebout M, Bekri S, Gauthier N, Hofman P, Poujeol $P$, Fénichel $P$, Mograbi B. Disruption of autophagy at the maturation step by the carcinogen lindane is associated with the sustained mitogenactivated protein kinase/extracellular signal-regulated kinase activity. Cancer Res 2006; 66: 6861-6870.

20. Chen S, Rehman SK, Zhang W, Wen A, Yao L, Zhang J. Autophagy is a therapeutic target in anticancer drug resistance. Biochim Biophys Acta 2010; 1806: 220-229.

21. Fukazawa H, Noguchi K, Murakami Y, Uehara $Y$. Mitogen-activated protein/extracellular signal-regulated kinase kinase (MEK) inhibitors restore anoikis sensitivity in human breast cancer cell lines with a constitutively activated extracellular-regulated kinase (ERK) pathway. Mol Cancer Ther 2002; 1: 303-309. 